\title{
CLINICAL AND LABORATORY ASPECTS OF ACUTE OBSTRUCTIVE BRONCHITIS IN CHILDREN INFECTED WITH MYCOPLASMA PNEUMONIAE
}

DOI: $10.36740 /$ WLek202006128

\author{
Svitlana H. Usenko', Zalina V. Yeloeva ${ }^{2}$, Maryna S. Diachenko², Serhiy A. Usenko ${ }^{2}$ \\ 'KHARKIV NATIONAL MEDICAL UNIVERSITY, KHARKIV, UKRAINE \\ ${ }^{2}$ KHARKIV MEDICAL ACADEMY OF POSTGRADUATE EDUCATION, KHARKIV, UKRAINE
}

\begin{abstract}
The aim of the work is to improve the prognosis of acute bronchitis on the basis of the study of etiology, clinical anamnestic and laboratory-instrumental features of acute bronchitis in children infected with Mycoplasma pneumoniae.

Materials and methods: Medical records of inpatients, data from laboratory and clinical examinations, orders from the Ministry of Health of Ukraine. Statistical processing of the obtained results was carried out with the calculation of parametric and non-parametric criteria. The study included 72 patients with acute obstructive bronchitis, infected with Mycoplasma pneumoniae and patients not infected with intracellular pathogens who were hospitalized under the conditions of pediatric ward of children of younger and older children of the National Children's Clinical Hospital №24.

Results: Found that infected with mycoplasma compared with uninfected intracellular infection, more characteristic course of acute obstructive bronchitis on the background of febrile temperature with its duration of more than 4 days, the presence of midbubble and single dry or wet rales, as well as. In general, in patients infected with mycoplasma, compared with patients infected with chlamydia, there is a higher functional stress of immunity with the phenomena of exhaustion.

Conclusions: Attention is drawn to the fact that clinical, laboratory data and immunological examinations with the use of systematic analysis make it possible to predict the consequences in the history of children with intracellular infections of various somatic pathologies. In doing so, multivariate and correlation analyzes make it possible to develop new diagnostic criteria.
\end{abstract}

KEY WORDS: acute obstructive bronchitis, intracellular pathogens, somatic pathology

Wiad Lek. 2020;73(6):1229-1233

\section{INTRODUCTION}

Respiratory diseases are one of the first places in the structure of childhood morbidity and remain an important problem in pediatrics. In recent years, the interest of pediatric pulmonologists to the problem of recurrent respiratory diseases has increased [1]. Acute obstructive bronchitis (AOB) is one of the most common forms of respiratory tract damage in children. In the structure of respiratory morbidity they are registered in $30-50 \%$ of cases [2]. Even a single obstructed bronchitis at an early age is dangerous because of the possibility of recurrent course, and in 47$57 \%$ of cases - transformation into bronchial asthma. The relevance of the study of acute obstructive bronchitis is due to the increase in frequency, regional features of the clinic, severity and prognosis of the disease.

Viral infections are among the factors that can cause the formation of secondary hyperreactivity bronchial of, which is observed in $53 \%$ of cases after suffering bronchopulmonary disease and can persist for 4-6 weeks after recovery, which increases the risk of recurrent bronchopulmonary diseases $[3,4]$. In the last 10-15 years, both acute and recurrent forms of bronchitis in school-age children have taken the leading place in Chlamydia pneumonia. In chil- dren 5-14 years Mycoplasma pneumoniae is the etiological agent of obstructive bronchitis in $21-35 \%$ of cases $[3,4]$.

\section{THE AIM}

The aim is to improve the prognosis of acute bronchitis on the basis of the study of the etiology, clinical and anamnestic and laboratoryi and instrumental features of acute bronchitis in children infected with Mycoplasma pneumoniae.

\section{MATERIALS AND METHODS}

The study included 72 children with acute obstructive bronchitis who were hospitalized in the department for young and elderly children of the National Pediatric Clinic "City Children’s Clinical Hospital №24” in Kharkiv. The Commission on Bioethics of the Kharkiv Medical Academy of Postgraduate Education (Protocol No. 05 of April 2017) found out that the conducted studies were in accordance with the ethical principles of medical research conducted on humans. The study was performed with minimal psychological loss for patients. To solve this problem, 
Table I. Distribution of patients in groups depending on the anamnesis data

\begin{tabular}{|c|c|c|c|c|c|c|}
\hline \multirow[t]{2}{*}{ Indicators } & \multirow[t]{2}{*}{ Grades of the indicator } & \multicolumn{2}{|c|}{$\begin{array}{l}\text { The main group } \\
\qquad \mathrm{n}=\mathbf{3 1}\end{array}$} & \multicolumn{2}{|c|}{$\begin{array}{c}\text { Control } \\
n=41\end{array}$} & \multirow[t]{2}{*}{$\mathbf{P}$} \\
\hline & & abs. & $\%$ & abs. & $\%$ & \\
\hline \multirow{2}{*}{ The course of childbirth } & physiological & 24 & 77,4 & 31 & 75,6 & $>0,05$ \\
\hline & caesarean section & 7 & 22,6 & 10 & 24,4 & $>0,05$ \\
\hline \multirow{3}{*}{ Pregnancy order number } & 1 & 22 & 71,0 & 19 & 46,3 & $<0,05$ \\
\hline & 2 & 7 & 22,6 & 13 & 31,7 & $<0,05$ \\
\hline & $\geq 3$ & 2 & 6,4 & 9 & 22,0 & $<0,05$ \\
\hline \multirow{2}{*}{ Pregnancy } & complicated & 21 & 67,7 & 27 & 65,9 & $>0,05$ \\
\hline & uncomplicated & 10 & 32,3 & 14 & 34,1 & $>0,05$ \\
\hline \multirow{3}{*}{ Birth weight, g. } & $\leq 2500$ & 2 & 6,4 & 6 & 14,6 & $>0,05$ \\
\hline & $2501-3000$ & 9 & 29,0 & 2 & 4,9 & $>0,05$ \\
\hline & $\geq 3001$ & 20 & 64,6 & 33 & 80,5 & $>0,05$ \\
\hline \multirow{4}{*}{ Breastfeeding, months } & $\leq 3$ & 7 & 22,6 & 16 & 39,1 & $>0,05$ \\
\hline & $3,1-6$ & 9 & 29,0 & 4 & 9,8 & $>0,05$ \\
\hline & $6,1-12,0$ & 5 & 16,1 & 3 & 7,3 & $>0,05$ \\
\hline & $\geq 12,1$ & 10 & 32,3 & 18 & 43,8 & $>0,05$ \\
\hline \multirow{3}{*}{$A R V I$ frequency at 1 year of age } & not sick & 9 & 29,0 & 21 & 51,2 & $<0,05$ \\
\hline & rarely & 8 & 25,8 & 14 & 34,2 & $>0,05$ \\
\hline & often & 14 & 45,2 & 6 & 14,6 & $<0,01$ \\
\hline \multirow[t]{3}{*}{ ARVI frequency after 1 year of life } & not sick & 10 & 32,3 & 13 & 31,7 & $>0,05$ \\
\hline & rarely & 5 & 16,1 & 21 & 51,2 & $<0,01$ \\
\hline & often & 16 & 51,6 & 7 & 17,1 & $<0,01$ \\
\hline
\end{tabular}

Table II. Diagnostic sensitivity of anamnestic parameters in patients with AOB

\begin{tabular}{ccc} 
Indicators & Sensitivity \% & Rank \\
\hline Pregnancy & 71,0 & 1 \\
\hline ARVI frequency at 1 year of age & 51,6 & 2 \\
\hline ARVI frequency after 1 year of life & 45,2 & 3 \\
\hline
\end{tabular}

comparisons of clinical and anamnestic and immunological parameters in alternative groups were performed: a) patients with $\mathrm{AOB}$ infected with mycoplasma $(\mathrm{n}=31$; main group); b) AOB patients uninfected with intracellular infection ( $n=41$; control group).

It follows from the study that the proportion of boys was significantly higher in the control group (68.3\%) than in the main group (45.2\%), and girls more often found in the main group (54.8\%) than in the control group (31.7\%). In the age aspect, the age of up to three years was characteristic of patients in the control group, as it was determined 3 times more often $(\mathrm{p}<0.01)$, and patients older than 3 years were found in $83.9 \%$ of patients in the main group and in 2, 6 times less $(\mathrm{p}<0.01)$ in control.

The examination consisted of determining the characteristics of complaints, medical history, objective status and laboratory methods of investigation. An immunological blood test included the determination of serum A, M, G immunoglobulins (Ig) by radial immunodiffusion according to Manchini et al .; determining the population and subpopulation of lymphocytes using monoclonal antibodies (CD3, CD4, $\mathrm{CD} 8, \mathrm{CD} 16, \mathrm{CD} 19, \mathrm{CD} 25)$; the level of circulating immune complexes (CIC) by the method of selective precipitation of polyethylene glycol (PEG) 3.5\%; in order to assess the phagocytic capacity of blood neutrophils, and in particular to determine the phagocytic number and index, the method proposed by DV Bilokrinitsky will be used; the bactericidal activity of neutrophils was evaluated according to the test with nitrosine tetrazolium (NST test) - according to G.Stuart (1983) in the modification of VS Nagoev. Statistical processing of the results was performed using standard programs for personal computer (Microsoft Excel, Statistica 6.0).

\section{RESULTS AND DISCUSSION}

During the analysis of premorbid background (table I), it was determined that according to a number of indicators significant differences between groups, were revealed and in patients infected with mycoplasma, significantly more often $(1.5$ times; $\mathrm{p}<0.05)$ than in control, children were 
Table III. Distribution of patients in groups according to clinical data

\begin{tabular}{|c|c|c|c|c|c|c|}
\hline \multirow{2}{*}{ Indicators } & \multirow{2}{*}{ Grading Indicators } & \multicolumn{2}{|c|}{ Core Group } & \multicolumn{2}{|c|}{ Control } & \multirow{2}{*}{$\mathbf{P}$} \\
\hline & & абс. & $\%$ & абc. & $\%$ & \\
\hline \multirow{2}{*}{ Body temperature } & $\leq 37,9$ & 14 & 45,2 & 27 & 65,9 & $<0,05$ \\
\hline & $\geq 38,0$ & 17 & 54,8 & 14 & 34,1 & $<0,05$ \\
\hline \multirow{2}{*}{ Duration of temperature increase, days } & $0-3$ & 12 & 38,7 & 28 & 68,3 & $<0,01$ \\
\hline & $\geq 4$ & 19 & 61,3 & 13 & 31,7 & $<0,01$ \\
\hline \multirow[t]{2}{*}{ Toxic syndrome } & IS & 23 & 74,2 & 26 & 63,4 & $>0,05$ \\
\hline & Does not & 8 & 25,8 & 15 & 36,6 & $>0,05$ \\
\hline \multirow{2}{*}{ Respiratory rate } & $\leq 32$ & 24 & 77,4 & 26 & 63,4 & $>0,05$ \\
\hline & $\geq 33$ & 7 & 22,6 & 15 & 36,6 & $>0,05$ \\
\hline \multirow{2}{*}{ Whistling wheezes } & IS & 11 & 35,5 & 23 & 56,1 & $<0,05$ \\
\hline & Does not & 20 & 64,5 & 18 & 43,9 & $<0,05$ \\
\hline \multirow{2}{*}{ Dry wheezing } & IS & 1 & 3,2 & 6 & 14,6 & $>0,05$ \\
\hline & Does not & 30 & 96,8 & 35 & 85,4 & $>0,05$ \\
\hline \multirow{2}{*}{ Medium-bubbling wet rales } & IS & 8 & 25,8 & 6 & 14,6 & $>0,05$ \\
\hline & Does not & 23 & 74,2 & 35 & 85,4 & $>0,05$ \\
\hline \multirow{2}{*}{ Single dry rales } & IS & 6 & 19,4 & 0 & 0 & $<0,05$ \\
\hline & Does not & 25 & 80,6 & 41 & 100 & $<0,05$ \\
\hline \multirow{2}{*}{ Single wet rales } & IS & 5 & 16,1 & 0 & 0 & $<0,05$ \\
\hline & Does not & 26 & 83,9 & 41 & 100 & $<0,05$ \\
\hline \multirow{2}{*}{ Duration of treatment, days } & $\leq 9$ & 7 & 22,6 & 19 & 46,3 & $<0,05$ \\
\hline & $\geq 10$ & 24 & 77,4 & 22 & 53,7 & $<0,05$ \\
\hline
\end{tabular}

born from the first pregnancy, 3.1 times $(\mathrm{p}<0.01)$ more often suffered from acute respiratory infections (ARVI) both in the first and after the first year of life of the child.

There were no significant differences between the groups regarding such indicators as the nature of labor and pregnancy, birth weight and duration of breastfeeding ( $p>0.05)$.

Due to the fact that according to a number of anamnesis indicators significant differences between groups, were revealed it allows them to be used for diagnostic purposes.

In the table II presents the diagnostic sensitivity of anamnestic data: moderate diagnostic sensitivity was characteristic for the order of pregnancy $(71 \%-1$ st rank), low - for the ARVI frequency after the first year of life (51.6\% - 1st rank) and the ARVI frequency at the first year of life (45.2\% - 3rd rank).

With regard to other clinical features (table III), patients of the main group were characterized by: duration of fever $\geq 4$ days ( $p<0.01$ ), and the presence of single dry $(\mathrm{p}<0.05)$ and moist rales $(\mathrm{p}<0.05)$. In addition, patients of the main group had a long ( $\geq 10$ days) duration of inpatient treatment, which occurred in $77.4 \%$, including significantly less $(\mathrm{p}<0.05)$ in the control group.
Therefore, the study indicates that mycoplasma infection of the child is significantly reflected in the clinical characteristics of $A O B$, which allows them to be used to diagnose mycoplasma infection in patients with AOB.

Analysis of the diagnostic sensitivity of clinical indicators showed that its moderate values were found for the duration of treatment ( $77.4 \%$ - 1st rank) and the duration of fever $(61.3 \%$ - 2nd rank), and low diagnostic sensitivity was characteristic of body temperature $(54.8 \%$ - 3rd grade), wheezing wheezing ( $35.5 \%$ - 4 th grade), single dry wheezing $(19.4 \%$ - grade 5) and single wet rales $(16.1 \%$ - 6th rank).

In determining the characteristics of the immune status of the studied groups in patients with GOB infected with mycoplasma (table IV), found that compared with the norm in patients revealed an increase of $33.7 \%$ of the absolute number of T-lymphocytes (CD3), T-suppressors (CD8) by $30.1 \%$, B-lymphocytes (CD22) by $73.8 \%$, and the relative content of T-lymphocytes helpers $(\mathrm{CD} 4)$ by $20.8 \%$ and B-lymphocytes by $30.8 \%$.

Decrease relative to the norm was found in relation to the phagocytic number by $15.7 \%$, spontaneous HCT test 
Table IV. The values of immunity in patients with AOB infected with Mycoplasma

\begin{tabular}{|c|c|c|c|}
\hline \multirow{2}{*}{ Indicators } & \multicolumn{2}{|c|}{$M \pm m$} & \multirow{2}{*}{$\mathbf{P}$} \\
\hline & Main group, $\mathbf{n}=31$ & Practically healthy, $n=20$ & \\
\hline CD3, \% & $66,7 \pm 0,87$ & $65,4 \pm 0,48$ & $>0,05$ \\
\hline CD3, abs. & $2,62 \pm 0,13$ & $1,96 \pm 0,10$ & $<0,001$ \\
\hline $\mathrm{CD} 4, \%$ & $35,5 \pm 0,70$ & $32,0 \pm 0,78$ & $<0,001$ \\
\hline CD4, abs. & $1,27 \pm 0,07$ & $1,15 \pm 0,03$ & $>0,05$ \\
\hline $\mathrm{CD} 8, \%$ & $26,1 \pm 0,52$ & $21,6 \pm 1,0$ & $<0,001$ \\
\hline CD8, abs. & $0,95 \pm 0,05$ & $0,73 \pm 0,03$ & $<0,001$ \\
\hline CD16, \% & $10,8 \pm 0,30$ & $12,3 \pm 1,20$ & $>0,05$ \\
\hline CD16, abs. & $0,40 \pm 0,02$ & $0,41 \pm 0,03$ & $>0,05$ \\
\hline $\mathrm{CD} 22, \%$ & $19,1 \pm 0,35$ & $14,6 \pm 0,54$ & $<0,001$ \\
\hline CD22, abs. & $0,73 \pm 0,04$ & $0,42 \pm 0,04$ & $<0,001$ \\
\hline CD25, \% & $14,1 \pm 0,69$ & $12,9 \pm 0,66$ & $>0,05$ \\
\hline CD25, abs. & $0,54 \pm 0,04$ & $0,37 \pm 0,03$ & $<0,01$ \\
\hline Phagocytosis, \% & $53,7 \pm 1,30$ & $48,9 \pm 0,78$ & $<0,01$ \\
\hline Phagocytic index & $1,56 \pm 0,14$ & $1,26 \pm 0,15$ & $>0,05$ \\
\hline Phagocytic number & $4,3 \pm 0,25$ & $5,1 \pm 0,05$ & $<0,01$ \\
\hline Total compliment, $\%$ & $57,9 \pm 1,13$ & $58,8 \pm 2,1$ & $>0,05$ \\
\hline $\begin{array}{l}\text { Circulating immune complexes with } \\
\text { 3.5\% PEG }\end{array}$ & $9,8 \pm 0,31$ & $8,1 \pm 0,42$ & $<0,001$ \\
\hline NST-spontaneous, $\%$ & $15,9 \pm 0,83$ & $24,7 \pm 2,16$ & $<0,001$ \\
\hline $\begin{array}{l}\text { The neutrophil activity index is } \\
\text { spontaneous, un. }\end{array}$ & $0,27 \pm 0,02$ & $0,25 \pm 0,02$ & $>0,05$ \\
\hline NST-stimulated, $\%$ & $51,4 \pm 1,1$ & $63,1 \pm 2,7$ & $<0,001$ \\
\hline $\begin{array}{l}\text { The neutrophil activity index is } \\
\text { stimulated, units }\end{array}$ & $0,28 \pm 0,02$ & $0,86 \pm 0,03$ & $<0,001$ \\
\hline Lysosomal cationic proteins, units & $1,20 \pm 0,008$ & $1,21 \pm 0,01$ & $>0,05$ \\
\hline $\lg A, g / l$ & $1,32 \pm 0,06$ & $0,62 \pm 0,02$ & $<0,001$ \\
\hline $\lg M, g / l$ & $1,0 \pm 0,06$ & $0,85 \pm 0,01$ & $<0,05$ \\
\hline $\lg G, g / l$ & $8,9 \pm 0,22$ & $7,7 \pm 0,17$ & $<0,001$ \\
\hline
\end{tabular}

by $35.7 \%$, stimulated NST test by $18.6 \%$, neutrophil activity index stimulated by $67.7 \%$.

In addition, in the group infected with mycoplasma compared with the standard there was an increase in phagocytosis by $9.8 \%$, the level of CIC from 3.5\% PEG by $21 \%$, IgA by $112,9 \%$, IgM by $17.6 \%$ and IgG by $15.6 \%$.

The analysis of the degree of deviation from the norm of values of indicators of the T-system of immunity found that moderate deviations from the norm were found in relation to the increase in the absolute number of CD3 $(\mathrm{t}=4,0$; $\mathrm{p}<0,001)$ and $\operatorname{CD} 8(\mathrm{t}=3,8 ; \mathrm{p}<0,001)$, and also the relative contents of $\mathrm{CD} 8(\mathrm{t}=4.0 ; \mathrm{p}<0.001)$. Moderate deviations are set for the increase in the relative number of CD4 $(\mathrm{t}=3.3 ; \mathrm{p}<0.001)$, and insignificant for the absolute content of CD25 $(t=2.8 ; \mathrm{p}<0.01)$. No significant differences were found from the standard for such indicators as the absolute number of CD4 $(\mathrm{t}=1.6 ; \mathrm{p}>0.05)$ and CD16 $(\mathrm{t}=0.1 ; \mathrm{p}>0.05)$, as well as the relative content of CD16, CD25 $(\mathrm{t}=1.2 ; \mathrm{p}>0.05)$ and CD3 $(\mathrm{t}=0.4 ; \mathrm{p}>0.05)$.
The above data indicate that activation of the T-system of immunity, which is a manifestation of compensation, is observed in patients with mycoplasma-infected GOB, but there is no adequate activation by natural killers, as well as a tendency to decrease the relative number of CD25, which determines hyperactivity and is a negative point and indicates an imbalance in the functioning of the T-system of immunity.

On the part of the B-system of immunity, pronounced deviations were found regarding the increase of IgA level $(\mathrm{t}=11.1 ; \mathrm{p}<0.001)$ and the relative content of CD22 $(\mathrm{t}=6.7 ; \mathrm{p}<0.001)$. The obtained data indicate hyperactivation of the B-system of immunity in this category of patients, aimed at the production of antibodies upon penetration into the body of an antigenic stimulus.

Therefore, in general, patients infected with mycoplasma, compared with patients infected with chlamydia, there is a higher functional impairment of immunity with the phenomena of overvoltage, ie exhaustion. 


\section{CONCLUSIONS}

1. For patients infected with mycoplasma compared with uninfected intracellular infection, more characteristic of the course of $\mathrm{AOB}$ on the background of febrile temperature with its duration of more than 4 days, the presence of midbubble and single dry or wet rales, as well as longer.

2. In patients with mycoplasma infection compared with patients without intracellular infection by $\mathrm{T}$ - system of immunity proved: higher values of the absolute number of $\mathrm{CD} 3, \mathrm{CD} 8$ and the relative content of $\mathrm{CD} 3, \mathrm{CD} 8$, as well as lower values of absolute and relative amount of CD16, as well as the absolute number of CD25.

3. On the part of the $B-$ immune system higher values of the relative number of CD22, IgA, IgG and low absolute amount of CD22; higher values of the phagocytic level of immunity: phagocytic number, spontaneous NST - test, neutrophil activation index of spontaneous and low phagocytosis; by the non-specific humoral immunity level - a higher CIC level with 3.5\% PEG.

4. In general, in patients infected with mycoplasma, compared with patients infected with chlamydia, there is a higher functional tension of immunity with the phenomena of exhaustion.

5. Significant differences between clinical and immunological parameters were proved between groups of patients with $\mathrm{AOB}$, depending on the presence of their infection with mycoplasma, which is the basis for the development of diagnostic criteria.

\section{REFERENCES}

1. Moiseienko R.0., Dudina 0.0., Hoida N. H. Analiz stanu zakhvoriuvanosti ta poshyrenosti zakhvoriuvan u ditei v Ukraini za period 2011-2015 roky [Analysis of the incidence and prevalence of diseases in children in Ukraine for the period 2011-2015]. Sovremennaia pedyatryia. 2017; №2(82):17-27. (Ua)

2. Boronyna L. H., Samatova E. V. Veryfykatsyia эtyolohyy obostrenyi khronycheskykhynfektsyonno-vospalytelnыkhzabolevanyilehkykh udetei [Verification of etiology of exacerbations of chronicinfectious-inflammatory lung diseases in children]. Pedyatryia. 2014; 5 (3): 9-15. (Ru)
3. Holubovska 0.A. Infektsiini khvoroby (pidruchnyk) [ Infectious diseases (textbook)]. In: Holubovska 0. A., Andreichyn M. A., Shkurba A. V. Kyiv: VSV «Medytsyna», 2 vydannia, dopovnene i pereroblene, 2018, p. 313-318. (Ua)

4. L.I. Chernyshova. Infektsiini khvoroby u ditei: pidruchnyk (VNZ IV r. a.) [Infectious diseases in children: a textbook (Higher education institution IV a.)]. In; L.I. Chernyshova, A.P. Volokha, A.V. Bondarenko ta in.; za red. L.I. Chernyshovoi. — 2-e vyd., vypr. Kyiv: Medytsyna; 2017, p. 10-16. (Ua)

5. Yeloieva Z. V., Matviienko S. 0., Diachenko M. S. Diahnostychne i prohnostychne znachennia vnutrishnoklitynnykh zbudnykiv u vypadku atypovoi infektsiinoi patolohii u ditei. [Diagnostic and prognostic value of intracellular pathogens in the case of atypical infectious pathology in children]. Problemy bezperervnoi medychnoi osvity ta nauky. 2017; 1 (24): 21-26. (Ua)

6. Shyrobokov V. P. Medytsynskaia mykrobyolohyia, vyrusolohyia y ymmunolohyia [Medical microbiology, virology and immunology]. Vynnytsa: Nova knyha; 2015, 898 p. (Ru)

The dissertation work was performed in accordance with the plans of the research work of the Department of Pediatrics of Kharkiv Medical Academy of Postgraduate Education "The role of modifying factors in the prognostic evaluation of bronchopulmonary, cardiovascular and rheumatic pathology in children" (state registration number 0117U0005596).

\section{ORCID and contributorship:}

Svitlana H. Usenko - 0000-0002-2567-7267 C

Zalina V. Yeloeva - 0000-0002-4703-188X ${ }^{A, F}$

Maryna S. Diachenko - 0000-0002-2006-3346 ${ }^{B, D}$

Serhiy A. Usenko - 0000-0003-3667-7251 ${ }^{E}$

\section{Conflict of interest:}

The Authors declare no conflict of interest.

\author{
CORRESPONDING AUTHOR \\ Maryna S. Diachenko \\ Kharkiv Medical Academy of Postgraduate Education \\ Av. Peremohi 57 b, 10, Kharkiv, Ukraine \\ tel: +380633058250 \\ e-mail:marynausenko@ukr.net
}

Received: 22.02.2020

Accepted: 30.04 .2020 